\title{
The Relationship between Implied Cost of Equity and Corporate Life Cycle Stages
}

\author{
Attaullah Shah * $\quad$ Khyber Khan ${ }^{\dagger} \quad$ Muhammad Afraz ${ }^{\ddagger}$
}

\begin{abstract}
This study develops and tests the hypothesis that the implied cost of equity declines as a firm passes through the growth, maturity, and stagnant stages of its life. We use the methodology of Anthony and Ramesh (1992) for identifying corporate life cycle stages. Three different models are used to calculate the implied cost of equity: the Easton (2004) model, the Gordon and Gordon (1997) model, and the Ohlson and Juettner-Nauroth (2005) model. For testing our hypothesis, we use data of all non-financial firms listed on the Pakistan Stock Exchange from 1996 to 2012. The results lend strong support to our hypothesis in both the univariate and multiple regression analyses. The results show robustness to using different models of implied cost of equity and controlling for well-known determinants of the cost of equity such as beta, idiosyncratic risk, market-to-book ratio, firm size, and leverage. Our findings imply that firm's age can serve as a useful indicator for shareholders and creditors in evaluating riskiness and information asymmetry of the firm.
\end{abstract}

Keywords: Corporate Life Cycle, Implied Cost of Equity, MPEG, Gordon, Ohlson and Juettner-Nauroth, Pakistan.

\section{Introduction}

For more than forty years, many fields of social sciences have applied the theory of corporate life cycle such as management, accounting, and finance etc. Despite this wealth of studies, it is still relatively unknown how shareholders see each stage of a firm's life cycle in terms of riskiness and how equity risk premium behaves in different stages of a firm's life cycle. In this paper, we explore several channels through which a connection between cost of equity and corporate life cycle stages can be established. First, we use information asymmetry theory to create a link between the two variables. Myers and Majluf (1984) argue that external equity financing is more exposed to adverse selection problems as compared to internally generated funds and debt financing in the presence of information asymmetry ${ }^{1}$. Based on these arguments, many studies have documented significant underpricing for

\footnotetext{
*Assistant Professor, Institute of Management Sciences, Peshawar, Pakistan.

E-mail: attaullah.shah@imsciences.edu.pk

${ }^{\dagger}$ Institute of Management Sciences, Peshawar, Pakistan.

${ }^{\ddagger}$ Institute of Management Sciences, Peshawar, Pakistan.

${ }^{1}$ The famous pecking order theory was first presented by Donaldson (1964) and later modified by Myers and Majluf (1984).
} 
equity offerings both across markets and across time periods. Equity underpricing reflects the concern of shareholders that they might be exposed to higher risk in absence of complete information. In the early stages of a firm's life, the firm is small and is relatively unknown to the market therefore, one would expect higher level of information asymmetry between the firm and external market. In return, shareholders will demand higher equity risk premium. As the firm grows older, the level of information asymmetry and hence the cost of equity are expected to decrease. One can argue that firms with higher information asymmetry problems can reduce their costs of capital by employing internally generated funds and debt financing as their first choice of financing. However, Fluck (2000) shows in a theoretical model that there is a life cycle stage-dependency in firms' choices of financial contracts. He argues that such dependency arises because of the control rights of subsequent claimholders, who in addition to their own rights, may also rely on the firms' existing investors to enforce their claims. His arguments imply that firms will rely more on equity and short-term debt in the early stages of their life cycles and will use retained earnings and long-term debt in the later stages of their lives.

Second, we use the risk-return trade-off framework to establish a relation between corporate life cycle stages and cost of equity. A firm in its early stages is small and faces higher cash flows uncertainty. In comparison, mature firms are presumably more diversified, larger in sizes, and have stable cash flows. They are better equipped to withstand economic shocks. Therefore, shareholders may demand higher risk premium on shares of young and growing firms and lower risk premium on shares of old and mature firms. And finally, firm resource-based view could be used to establish a link between cost of equity and corporate life cycle stages. Under the dynamic resource-based view, firms constantly undergo changes and acquire unique resources which can be used to get competitive advantage over others (Penrose, 1959; Rumelt, 1984; Wernerfelt, 1984). As a firm progresses through its life stages, the resources/capabilities set varies, and in turn, can attract potential shareholders toward the firm. At a life stage where the firm has acquired highly valuable and unique resources, there will be substantial demand for its shares which in turn would increase liquidity of the shares and reduce the equity premium (Hasan, Hossain, Habib, et al., 2015). Considering the above, we expect that the implied cost of equity systematically declines as a firm passes through the stages of its life cycle. It is also likely that firms in later stages of their lives will face more default risk, given that if they do not change their capital structures. However, since firms are dynamic in responding to their internal and external factors, it is more likely that they change their capital structures so that the declining ability to pay debt is matched with the lower leverage on their balance sheet. In fact, La Rocca, La Rocca, and Cariola (2011) found that firms in later stages of their lives replace leverage with internal equity, which supports our view.

This paper contributes to the existing literature in two respects. First, over the past 50 years, investigating cost of equity is a continuing concern within corporate finance and investment research. Supporters of the efficient market hypothesis as well as the behavioral finance are still struggling to develop consensus on what risk factors can satisfactorily explain the equity risk premium. In this regard, our study adds an important dimension to the determinants of cost of equity or equity risk premium. As mentioned earlier, despite the importance of corporate life cycle theory and cost of equity, the role of the former 
in explaining variations in cost of equity has not attracted much attention, with notable exception of Hasan et al. (2015). However, our paper is different from Hasan et al. (2015) in several ways. First, Hasan et al. (2015) used only firms' resource-based view in developing their hypotheses. Specifically, they hypothesized that at the introduction and decline stages of a firm's life cycle, the implied cost of equity is higher; whereas, it is lower at the growth and maturity stages. They assumed that the set of unique resources that a firm accumulates over its life cycle stages loses value in the stagnancy stages which results in higher implied cost of equity. Our hypotheses are motivated by asymmetric information, risk-return trade-off, and the resource-based view. We assume that as the firm grows older, information asymmetry and the firm's riskiness should systematically decrease while the set of technical skills and product market experiences should increase. These features should systematically reduce the implied cost of equity of the firm. Therefore, we do not expect the implied cost of equity to increase in the stagnant stage. Second, we use different models for identifying corporate life-cycle stages and implied costs of equity. This differentiation is important because the literature on the given topic is still emerging. Hence, this area of research warrants further investigation using lenses of different theories, using data sets from different markets and different time periods, and using different models of corporate life cycle stages and implied cost of equity. Thus, our paper contributes to the literature which is emerging and seeks to come up with blocks that are missing from the equity premium puzzle.

Second, we try to test our hypotheses using Pakistani data while Hasan et al. (2015) used a sample of Australian firms. We argue that studying Pakistani market is important for two reasons. First, literature suggests that information asymmetry problems are likely to be greater in developing and emerging markets ${ }^{2}$. Since our hypotheses are motivated by asymmetric information and risk-return trade-off, Pakistan is a good candidate for our tests as Pakistan is a developing country. Second, in the last decade, Pakistan's equity market attracted substantial amount of foreign portfolio investment and delivered equity returns that were hard to ignore ${ }^{3}$. Pakistan Stock Exchange (PSX) was ranked as one of the top performers in the year 2013 by the Wall Street Journal ${ }^{4}$.

The literature is rich in terms of conceptual and empirical evidence that public limited companies have poor transparency and quality of disclosures in the East Asian countries (Fan \& Wong, 2002). One of the reasons for poor disclosure quality is the presence of family firms and insider block holders. This is contrary to the developed countries where dispersed ownership is ubiquitous. Since Pakistani corporate landscape is characterized by family businesses, group and associated companies, insider-controlled firms, and crossholdings, we believe that Pakistan presents a typical case which is different from other countries in the developed regions of the world. Further, Pakistan is not much different from other South Asian countries and selecting any other country from this region is as much justifiable as Pakistan.

\footnotetext{
${ }^{2}$ Studies such as Jabeen and Shah (2011), Balasubramanian et al. (2010), (Seifert \& Gonenc, 2012), and Stiglitz (1989) provide evidence that information asymmetry problems are higher in developing/emerging countries.

${ }^{3}$ The foreign portfolio investors injected around $\$ 404$ million in the KSE in the year 2013, according to National Clearing Company of Pakistan (NCCPL).

${ }^{4}$ Wall Street Journal, "Daring Investors Brave Pakistan Market" Jan. 3, 2014.
} 
Further, it is relevant to highlight that many South Asian countries have striking similarities. Mallik and Chowdhury (2001); Cooray, Paradiso, and Truglia (2013) argue that Pakistan, Sri Lankan, Bangladesh and India can be considered a homogenous group of countries on the basis of economic performance, economic characteristics, structure of output, technology, culture, education, and capital accumulation. The fact that a similar study does not exist in the South Asian region, our results have thus relevance to a broad range of countries, not just Pakistan.

\section{Review of Literature}

Our literature is organized in two parts. The first part discusses different models of cost of equity and their assumptions. The second part focuses on firm life cycle models to understand what stages a firm passes through its life cycle and how each stage is different from the others in terms of riskiness and expected cost of equity. Discussion in this section helps us in deriving testable hypotheses.

We have employed a systematic approach to selecting and reviewing papers in this section. The criteria for selection in this regard was (i) relevance of the studies to cost of equity and corporate life cycle (ii) high number of citations (iii) ground-breaking or pioneering studies (iv) recent publications. In this review of literature, the oldest research study is of Miller and Friesen (1984), whereas the latest research study is of (Hasan et al., 2015).

\section{Theory and Cost of Equity Models}

Cost of equity refers to the rate of return which shareholders demand on their investment. Cost of equity measure is also helpful for managers as they need it for capital budgeting decisions (Botosan \& Plumlee, 2005). The cost of equity is not directly observable or recorded in financial statements, rather it is calculated through asset pricing models or derived from current share prices and future expected cash flows. When shareholders demand a higher return from a share, they adjust the share price downward until they get required rate of return on their investments. There is a general agreement that this return should be larger enough to compensate shareholders for the opportunity cost and the risk associated with their investments. However, the specific proxies that are used to capture riskiness of a firm have substantial controversies around them. The Capital Asset Pricing Model of Sharpe (1964); Lintner (1965); F. Black (1972) assumes that investors hold the market portfolio which has all types of risky assets. This portfolio is completely diversified and serves as a benchmark for calculation of risk premium on individual assets. An asset's riskiness is measured by beta which is the covariance of an asset with the market portfolio divided by variance of the portfolio. Though CAPM is being widely used by practitioners, extant literature shows that CAPM could not stand firm to the empirical tests (Fama \& French, 1992; McNulty, Yeh, Schulze, \& Lubatkin, 2002) ${ }^{5}$. Specifically, one

\footnotetext{
${ }^{5}$ CAPM suggests a positive relationship between risk and return. However, empirical evidence on the sign of this relationship is inconclusive, specifically when the relationship is tested inter-temporally. Several
} 
of the issues with using CAPM in emerging markets is that the stock returns and betas are uncorrelated, (Estrada, 2001). Also, reliance of CAPM on past noisy data and the indifference of the holding period are the other two shortcomings of CAPM (Pástor, Sinha, \& Swaminathan, 2008). Also, CAPM predicts that beta alone can explain variation in observed equity risk premiums, a number of studies have found other firm-specific factors that can explain variations in observed equity risk premiums along with beta. For example, Banz (1981) showed that size effect has a huge role in explaining observed equity returns. He showed that returns on small firms were substantially higher than what their betas would suggest. Other firm-specific factors that influence cost of equity include book-tomarket ratio (Stattman, 1980); leverage (Bhandari, 1988); price-to-earnings ratio (Basu, 1983); and a set of macro factors (Ross, 1977). As a general conclusion, (Lee, So, \& Wang, 2010) argued that the standard asset pricing models have failed to provide precise estimates of the cost of equity so far.

Compared to estimating cost of equity using standard asset pricing models, researchers find implied cost of equity (ICC) estimates more accurate in a sense that ICC estimates move closely with risk factors. ICC is the discount rate that equates the present value of all future cash flows to the market value of an asset (Thompson \& Wong, 1996). One of the appealing features of ICC is that it does not calculate cost of equity from noisy observed returns (Pástor et al., 2008). The accounting literature shows that a variety of approaches have been developed for estimating ICC, (Gordon \& Gordon, 1997; Claus \& Thomas, 2001; Gebhardt, Lee, \& Swaminathan, 2001; Ohlson \& Juettner-Nauroth, 2005) and Modified Price-Earnings Growth (MPEG) (Easton, 2004). All these models consider futuristic returns instead of historical returns, (Daske, Gebhardt, \& Klein, 2006). Pástor et al. (2008) suggest that all these approaches should be useful in capturing some or all aspects of the temporal variations in the expected returns. Hence, taking a stance on a given model of ICC is not required. Similarly, Hasan et al. (2015) argue that there is a lack of consensus on the precision of ICC estimates generated by different models. Therefore, a plausible approach would be to estimate ICC with different models for robustness of the results. In this paper, we use three different models for the calculation of ICC. The first models is the modified price-to-earnings growth (MPEG) model that was originally presented by Easton (2004) and modified by Gode and Mohanram (2003). The reason we choose this model is that Botosan and Plumlee (2005) presented evidence that ICC estimates of MPEG closely relate to different risk measures. The second model is the (Gordon \& Gordon, 1997) model which is the most parsimonious model among all ICC models, yet its estimates of ICC are highly correlated with the estimates of other models. The third model is the modified version of Ohlson and Juettner-Nauroth (2005) for the calculation of ICC ${ }^{6}$. Hasan et al. (2015) argued that OJ model is quite rigorous theoretically, yet it is parsimonious, and provides a closed form solution for the calculation of ICC. Details of these models are given in the methodology section.

studies have found a positive relationship (e.g., Ghysels, et al. (2005), Lundblad (2007), and Ludvigson and $\mathrm{Ng}$ (2007)), yet others have found a negative relationship (Glosten, Jagannathan, \& Runkle, 1993; Lettau, Ludvigson, \& Wachter, 2007; Brandt \& Kang, 2004) Harvey 2001.

${ }^{6}$ Gode and Mohanram (2003) modified Ohlson and Juettner-Nauroth (2005) for easy implementation of the model. 


\section{Cost of Equity and Corporate Life Cycle Stages}

There is a strong agreement among academicians that the corporate development is a structured process, though the set of variables they use for explaining this process is very different (Miller \& Friesen, 1984). Past literature shows that about 40 different models of corporate life cycle theory have been presented (Shirokova, 2009). Whereas Phelps, Adams, and Bessant (2007) highlighted in their review that there are 33 different corporate life cycle models, each having different set of variables and specific set of stages. Some of the famous corporate life cycle models include Lippitt and Schmidt (1967) model, Greiner (1998) model, Miller and Friesen (1984) model, Anthony and Ramesh (1992) model and Lester, Parnell, and Carraher (2003) model.

We prefer to use Anthony and Ramesh (1992) model for identifying different stages of corporate life cycle. This model is parsimonious with the additional advantage that its inputs are available in the data set that we use. Anthony and Ramesh (1992) model classifies firms into three distinct stages of firm life cycle, i.e. (i) growth, (ii) maturity and (iii) stagnant or decline stage, using univariate and multivariate ranking procedure. Anthony and Ramesh (1992) used four different variables for calculating these three stages i.e. sales growth, dividend payout, capital expenditure and age of the firm ${ }^{7}$. According to Anthony and Ramesh (1992), a firm at its growth stage is young with regards to its age, has high level of capital expenditure and sales growth and maintains low dividend payout policy. In the maturity stage of corporate life cycle, the firm reaches the adult stage and remaining three measures i.e. sales growth, dividend payout and capital expenditure exhibit medium levels in terms of value. And at the stagnant stage, the firm is old in terms of age, having high level of dividend payout and low levels of capital expenditure and sales growth.

As far as the risk level and implied cost of equity in each stage are concerned, we build premises for our hypotheses from three different dimensions. First, we highlight the role of asymmetric information in determining ICC in different stages of corporate life cycle. Pettit and Singer (1985) argue the information asymmetry problems are more severe with smaller and younger firms because it is costly for them to generate and disseminate information about themselves. The information asymmetry problem creates, what (La Rocca et al., 2011) termed as, 'reputational effect'. Young firms without track records and past experience cannot enjoy easy and cheap access to external finance. Vice versa, mature firms have past record of profitability, credibility, and reliability in the product market, and enjoy good reputations which they can spend in the financial markets (Diamond, 1989). La Rocca et al. (2011) argue that older firms have more chances of sound reputation in the product market and lower moral hazard problems which in turn help them to access external financing at favorable terms.

One can argue that information asymmetry problems make equity financing costlier, hence young firms should use less equity financing. However, Fluck (2000) argues that there is a life cycle stage-dependency in firms' choices of financial contracts. He attributes this dependency to the control rights of subsequent claimholders, who in addition to their own

${ }^{7}$ Anthony and Ramesh (1992) argue that the selection of these variables was motivated by their frequent use in similar contexts. 
rights, may also rely on the firm's existing investors to enforce their claims. His arguments imply that firms will rely more on equity and short-term debt in the early stages of their life cycles and will use retained earnings and long-term debt in the later stages. The implications of Fluck (2000) model can be related to the prediction of the pecking order theory which was popularized by Myers (1984); Myers and Majluf (1984). The pecking order theory suggests that the problem of information asymmetry is severe with external equity financing and less severe with the debt financing. However, internally generated funds do not have this problem; therefore, firms should first rely on internally generated funds for financing their needs to reduce the cost of capital. Since young and growing firms are expected to have financing needs greater than internally generated funds, they have to resort to external financing, which according to Fluck (2000) model should be equity and short-term debt. Also, Seifert and Gonenc (2012) argue that young and growing firms issue stocks because they have large investment opportunities, yet low level of earnings. Hence, it is expected that young firms face higher ICC than mature firms and stagnant firms.

Second, we borrow arguments from the risk-return trade-off framework. Firms in the growth phase are new to the market and are usually smaller in size (Konečnỳ, 2013; E. L. Black, 1998). Given that younger firms lack experience and walk in uncharted waters, it is expected that they face higher level of operational risk. Dickinson (2011) considered different cash flow patterns and used them as proxy for corporate life cycle. According to Dickinson (2011), the cash flows from operations and investing are negative in the beginning stages of firm life cycle. These negative cash flows are a reflection of the high operational risk, which increases the cost of capital. Moreover, Titman and Wessels (1988) argue that smaller firms have poor capacity to absorb macro-economic shocks as they lack sufficient resources base. As the firm passes through different stages of its life cycle, it gradually grows in size and diversifies its business lines. Larger size and product line diversification make the firm's cash flows stable and less sensitives to macro-economic shocks. Furthermore, this in turn should decrease the expected return on its shares (i.e. implied cost of equity).

Third, dynamic resource-based view implies that firms constantly undergo changes and acquire unique resources which can be used to get competitive advantage over others (Penrose, 1959; Rumelt, 1984; Wernerfelt, 1984). The resources / capabilities set varies as the firm progresses through its life cycle stages, and in turn can attract potential shareholders. In the early stage of its life cycle, a firm is less likely to acquire highly valuable and unique resources, and hence cannot attract substantial demand for its shares. Poor demand makes its shares illiquid and results in higher equity premium (Hasan et al., 2015). We test multiple theories to increase robustness of the results. The rationale for testing multiple theories is to see the marginal effect of each theory in influencing the implied cost of capital (ICC) at each stage of the life-cycle. Focusing on a single theory might prevent us from understanding the isolated effect of each theory which may overestimate or underestimate the parameters. Moreover, since the study relates the ICC with different life cycle stages of the firm, it becomes pertinent to know whether the level of ICC is explained equally by all theories as a firm passes through different stages.

In line with the above arguments, we develop and test the following hypotheses (stated 
in alternative form):

$H_{1}$ : An inverse relationship exists between implied cost of equity capital and stages of corporate life cycle.

The above hypothesis can be further divided into two sub-hypotheses;

$H_{1 a}$ : Cost of equity is lower in maturity and stagnant stages as compared to the growth stage.

$H_{1 b}$ : Cost of equity is lower in stagnant stage as compared to the maturity and growth stages.

\section{Methodology}

\section{Sample and Data Sources}

There is a total of 535 financial and non-financial firms listed at the Pakistan Stock Exchange as of December 31, $2012^{8}$. These firms are divided into 35 sectors. Since financial firms have quite different capital structures and are regulated differently, we exclude all financial firms from the analysis. The total number of non-financial firms listed at the Pakistan Stock Exchange is 425. Initially, we planned to include all non-financial firms in the analysis from year 1996 to 2012, subject to the fulfillment of the following criteria. (i) Firms should have positive shareholders' equity (ii) Firms should have data of at least five consecutive years. Additionally, firm-year observations that were above the 99 th percentile and below 1st percentile were dropped. Finally, we were left with 365 firms and 6205 firm-year observations.

The cost of equity models use market values of equity and predicted earnings. Generally, firms with higher market values have lower implied cost of equity. In order to have stable estimates of the cost of equity, we chose the period of 2006 to 2012 for the calculation of implied cost of equity (the first period from 1996-2005 is used for parameter estimation of equation 6). During this period, the KSE-100 index showed a moderate increase that is matched with the historical long-term average of the market. After 2012, the index experienced an exceptional increase which was significantly higher than the historical average. Therefore, we did not consider years after 2012 .

The data is gathered from the State Bank of Pakistan's published Balance Sheet Analysis reports. Every year State Bank of Pakistan publishes Balance Sheet Analysis report that contains key financial data of KSE listed firms for the period of six years. These Balance Sheet Analysis reports were collected from the website of the State Bank of Pakistan ${ }^{9}$. The data for the calculation of firms' age variable was collected from the website of Securities and Exchange Commission of Pakistan ${ }^{10}$ and from the Website of Euromoney

\footnotetext{
${ }^{8}$ Source: www.ksestocks.com.

${ }^{9}$ www.sbp.org.pk.

${ }^{10}$ www.secp.gov.pk
} 
Institutional Investor Company ${ }^{11}$. Share prices data, daily market index data, and data required for the calculation of control variables was collected from the website of Pakistan Stock Exchange ${ }^{12}$ and Business Recorder ${ }^{13}$.

\section{Models and Variables}

As highlighted in Section 2.1, standard asset pricing models such as CAPM are not a preferred choice for estimating cost of equity. The accounting literature offers several alternative models that derive implied cost of equity (ICC) from future expected cash flows and current market price of an asset. We use three implied cost of equity models i.e. Gordon and Gordon (1997) growth model, the Ohlson and Juettner-Nauroth (2005) model, and the modified price-to-earnings growth model (MPEG), presented by Easton (2004). We also use average implied cost of equity (Mean_ICC) of the three models as a robustness check ${ }^{14}$. As mentioned below, these three models are parsimonious, yet theoretically rigorous and offer a close end solution of ICC.

The Gordon and Gordon (1997) growth model is given in Equation 1.

$$
M_{t}=\frac{E_{t}\left[E_{t}+1\right]}{R}
$$

Where $M_{t}$ is the current market price of equity, $\left[E_{t}\right]$ shows market expectation based on information available in year $t, E_{t+1}$ is the forecasted earnings of the firm in year $t$ and $R$ is the implied cost of equity capital to be calculated. This is a special case of the finite-horizon version of the Gordon growth model.

The Ohlson and Juettner-Nauroth (2005) model is given in Equations (2) to (4).

$$
R=\sqrt{A^{2}+\frac{e p s_{1}}{P_{o}}(g-(\gamma-1))}
$$

Where,

$$
\begin{gathered}
A=0.5\left((\gamma-1)+\frac{d p s_{1}}{P_{o}}\right) \\
g=0.5\left(\frac{E_{t}\left[e p s_{3}\right]-E_{t}\left[e p s_{2}\right]}{E_{t}\left[e p s_{2}\right]}+\frac{E_{t}\left[e p s_{5}\right]-E_{t}\left[e p s_{4}\right]}{E_{t}\left[e p s_{4}\right]}\right)
\end{gathered}
$$

Where $\left[E_{t}\right]$ shows market expectation based on information available in year $t, P_{0}$ is current share price, $e p s_{1}$ is the forecasted earnings per share for year $1, d p s_{1}$ is forecasted dividend per share for year $1, e p s_{2}$ is forecasted earnings per share of two years ahead, $\gamma$ is assumed perpetual growth rate, $R$ is the implied cost of equity capital, and $g$ is the short-term growth rate. We follow (Gode \& Mohanram, 2003) and use the average of

\footnotetext{
${ }^{11}$ www.securities.com/emis/

12 www.kse.com.pk

13 www.brecorder.com.

${ }^{14}$ Several studies have proposed using average ICC from different models. This ensures that the ICC estimates are not driven by a specific model (Hasan et al., 2015; Hou, Van Dijk, \& Zhang, 2012).
} 
forecast two-year growth and five-year growth as an estimate of $g$. The OJ model uses $\gamma$ to represent perpetual growth in abnormal earnings. Gode and Mohanram (2003) modified the OJ approach to accommodate inflationary effects in the forecasts of earnings. For this purpose, they used the real perpetual growth rate to be equal to a very long-term economic growth rate of $3 \%$ and estimated $\gamma-1$ as risk-free rate minus three percent i.e. $\gamma=R f-3 \%$. Using the same logic, we measure long-term economic growth rate by the growth rate in gross domestic product (GDP). The risk-free rate has averaged approximately 8 percent and economic growth rate of 5 percent during the period of 1996 to 2012 in Pakistan; therefore, we set $(\gamma-1)=3 \%$ (i.e., $8 \%-5 \%)^{15}$.

The modified price-to-earnings growth model presented by Easton (2004) is as follows;

$$
M_{t}=\frac{E_{t}\left[E_{t+2}\right]+R * E_{t}\left[D_{t+1}\right]-E_{t}\left[E_{t+1}\right]}{R^{2}}
$$

Where $M_{t}$ is the current market price of shares, $E_{t+1}$ and $E_{t+2}$ are the forecasted earnings per share for year 1 and year 2 , respectively, $D_{t+1}$ is the forecasted dividend for year 1 and $R$ is the implied cost of equity capital to be calculated. We follow Hou et al. (2012) for calculating the value of dividend payout. They calculate $D_{t+1}$ as the dividend in year $t+1$, computed using the current dividend payout ratio for firms with positive earnings, or using current dividends divided by $0.06 \times$ total assets as an estimate of the payout ratio for firms with negative earnings.

There are many growth models, and not only proposed by Ohlson and Juettner-Nauroth (2005) and Gode and Mohanram (2003). For example, Wong and Chan (2004) provide a time-varying approach to estimate the cost of capital. However, the reason we prefer other models is that these models have been widely used recently in the calculation of ICC.

All the three models require forecasted earnings of one and two year ahead. In many countries, the forecasted earnings for selected firms are provided by systems such as I/B/E/S, etc., whereas in Pakistan, there is no organized database where analysts' forecasted earnings are maintained for firms listed at the Pakistan Stock Exchange ${ }^{16}$. Though forecasted earnings of one period ahead is provided by Khaddim Ali Shah Bukhari (KASB) securities for a limited number of firms; however, using that data would make the sample of this study so small to be taken seriously.

For forecasting earnings, we follow the methodology of Hou et al. (2012), who forecasted earnings for a large sample of firms listed on NYSE, Amex, Nasdaq, for the period of 1968 to 2008 through a cross-sectional model for up to a period of 5 years in future. They found that the forecasted earnings generated by their model were superior as compared to the forecasted earnings estimates of analysts. Their pooled cross-sectional regression model for forecasted earnings is shown in Equation (6). Specifically, for each year between 1996 and 2007, we estimate the following pooled cross-sectional regressions using the previous

\footnotetext{
${ }^{15}$ We have also used the $\gamma=\operatorname{Rf}-3 \%$ as suggested by Gode and Mohanram (2003) for checking robustness of the results. The results do not show sensitivity to using $\gamma=\mathrm{Rf}-3 \%$ as a measure of perpetual growth.

${ }^{16}$ Institutional Brokers' Estimate System (I/B/E/S) is a system generated by Thompson Reuters which provide forecasted estimates of key performance indicators of firms across developed countries. The estimates are provided by various stock analysts which help investors to analyze these estimates at one place without having to search for individual analyst's forecasts.
} 
10 years of data:

$$
E_{i, t+\tau}=\alpha_{0}+\alpha_{1} A_{i, t}+\alpha_{2} D_{i, t}+\alpha_{3} D D_{i, t}+\alpha_{4} E_{i, t}+\alpha_{5} N e g E_{i, t}+\alpha_{6} A C_{i, t}+\epsilon_{i, t+\tau}
$$

Where $E_{i, t+\tau}$ is the forecasted earnings of a firm i in year $t+\tau(\tau=1$ ton $), A_{i, t}$ is the value of total assets of firm $i$ in year $t, D_{i, t}$ is the dividend amount paid by the firm in current year, $D D_{i, t}$ is a dummy variable which equals one if a firm pays dividend and zero otherwise, $E_{i, t}$ is the earnings of the firm for current year and is equal to earnings before interest and tax expenses (EBIT), $N e g E-i, t$ is a dummy variable that equals one for firms with negative earnings and zero otherwise; and $A C_{i, t}$ shows accruals of the firm for current period. Hou et al. (2012) calculated accruals using two methods i.e. using balance sheet method and the cash flow statement method. Accruals under the balance sheet method are equal to the changes in non-cash current assets less changes in current liabilities, excluding the changes in taxes payable minus depreciation and amortization and changes in short-term debt. Whereas accruals in cash flow statements method are equal to the difference between earnings and cash flows from operations. Since the data for cash flows statement method was not available for all non-financial firms of Pakistan that is why we use the balance sheet method for calculation of accruals.

For each firm $i$ and in year $t$, we forecast earnings for up to 5 years into the future by multiplying the independent variables as of year $t$ with the coefficients from the pooled regression estimated using the previous ten years of data. According to Hou et al. (2012), this method ensures that the earnings forecasts are strictly out of sample. Furthermore, we only drop firm-year observations where the independent variables have missing values in year t to estimate earnings' forecasts. This ensures that the survivorship bias is kept to a minimum ${ }^{17}$. Since, we use 10-years of data for estimating coefficients of the pooled regression, the forecasted EPS data is available from year 2006 to 2012 for calculation of implied cost of equity.

\section{Model and Variables of Corporate Life Cycle Stages}

Anthony and Ramesh (1992) considered four variables for capturing growth stage, maturity stage, and stagnant stage of a firm's life cycle. These four variables are sales growth (SG), annual dividends as percentage of income (DPO), capital expenditure value (CAPEX) and firm age in years. These four variables are calculated as follows;

Sales growth $(\mathrm{SG})=\left[\right.$ sales $_{i, t}-$ sales $_{i, t-1} /$ sales $\left._{i, t-1}\right]$

Dividend payment $(\mathrm{DPO})=\left[D P S_{t} / E B I T_{t}\right]$

Capital expenditure value $(\mathrm{CAPEX})=[$ capital expenditure / market value of firm]

$\mathrm{AGE}=$ Difference between current year and the year of incorporation

Where, Sales $_{t}=$ net sales in current year.

$D P S_{t}=$ dividend per share in current year.

\footnotetext{
${ }^{17}$ Survivorship bias refers to the selection of only those firms who survived during the sample period and dropping those who had less data due to delisting, bankruptcy, or other reasons. Usually, survivorship bias can result in over-estimation of a phenomenon, i.e. the results reflect only those firms that are very strong (Brown, Goetzmann, Ibbotson, \& Ross, 1992).
} 
$\mathrm{EBIT}=$ Earnings before interest and tax expense.

Capital expenditure $=$ net change in fixed assets plus depreciation in current year.

Market value of the firm $=$ market value of equity plus book value of long term debt.

We follow the methodology of Anthony and Ramesh (1992) for classifying firms into life cycle stages using composite criteria. For each year i and in each year t, we calculate DPO, SG, CAPEX, and AGE. Then we calculate the median values of these variables (excluding AGE) based on prior five years data. Whereas the variable age is the difference between current year and year in which firm was formed. Then we rank firms on the basis of these four variables (i.e. AGE and median values of DPO, SG, and CAPEX) and group them in to different life cycle stages i.e. (Low, Medium and High for the three financial variables and young, adult, and old for the AGE variable), as per the criteria given in Table 1. After classifying firms into the mentioned groups, scores of 1, 2, and 3 are assigned to each firm in each year such that growing firms have a score of 1, mature firms have score of 2 , and stagnant firms have a score of 3 . Then we form a composite life cycle descriptor $\left(L C_{C} O M P\right)$ by summing up the scores of each individual variable and then ranking firms on the basis of this total score. The reason we use a composite criterion for forming a life cycle proxy is that firm life cycle is not clearly observable. Therefore, researches must find a life cycle descriptor which captures life cycle effects but is orthogonal to other effects which might confound the relationship. Three of the life cycle descriptors, i.e. sales growth, capital expenditures, and dividends, are easily related to firm risk. To minimize the effect of possible correlation of risk with life cycle stages, Anthony and Ramesh suggest adding variables that are both financial and nonfinancial in nature. Therefore, they added firm's age as a non-financial variable while the other three were financial in nature. The composite value is less likely to be affected by a specific phenomenon other than life cycle.

Table 1

Expectations for Firm Specific Descriptors of Life Cycle Stages

\begin{tabular}{|c|c|c|c|c|c|}
\hline Life Cycle Stages & Stage Score & Dividend Payment & Sales Growth & Capital Expenditures & Age \\
\hline Growth & 1 & Low & High & High & Young \\
\hline Maturity & 2 & Medium & Medium & Medium & Adult \\
\hline Stagnant & 3 & High & Low & Low & Old \\
\hline
\end{tabular}

\section{Empirical Model and Estimation of Variables}

To test the relationship between ICC and corporate life cycle stages, we estimate the following fixed effects model;

$$
I C C_{e, i t}=\alpha_{i}+\gamma_{j}+\beta_{0}\left(C L C_{i, t}\right)+\sum_{i=1}^{n} \beta_{i}\left(Z_{i, t}\right)+\epsilon_{i, t}
$$

Where $I C C_{e, i t}$ represents implied cost of equity calculated with model $e$ that ranges from 1 to 4 , for firm $i$ in year $t, a_{i} a n d \gamma_{j}$ refer to industry and years' fixed effects, $C L C_{i t}$ represents corporate life cycle proxies calculated through Anthony and Ramesh (1992) model for firm $i$ in year $t$, and $Z_{i t}$ represents a vector of five control variables that include 
firm size, leverage, book-to-market ratio, beta, and idiosyncratic risk. We used Hausman (1978) test to select between random and fixed effects models. The results favor the use of fixed effects model with year and industry dummies (i.e. the model we have already reported. Please note that our model is not OLS in its strict sense as it has year and industry dummies). Results of the Hausman test are given below:

\begin{tabular}{lcccl}
\hline & fixed & random & Difference & S.E. \\
\hline LC_COMPO & -0.0494 & -0.0448 & -0.0046 & 0.0098 \\
Beta & 0.008 & -0.0209 & 0.0289 & 0.0078 \\
SE & 1.2266 & 1.389 & -0.1624 & 0.1924 \\
size & 0.044 & -0.0152 & 0.0592 & 0.0092 \\
leverage & -0.0049 & 0.0589 & -0.0638 & 0.0303 \\
BM & -0.0001 & 0.0001 & -0.0002 & 0.0001 \\
Chi2 $(6)$ & 80.28 & & & \\
Prob $>$ Chi2 & 0.000 & & & \\
\hline
\end{tabular}

To test Hypotheses $H_{1 a}$ and $H_{1 b}$, we define three dummy variables for life cycle proxy. For example, for LC_COMP (which is composite life cycle descriptor based on four firmspecific variables as shown in Table 1), we define a dummy variable 1. LC_COMP that takes the value of one if LC_COMP is equals to one, otherwise zero; then we define 2 . LC_COMP that that takes the value of one if LC_COMP is equals to two, otherwise zero; and define 3. LC_COMP that takes the value of one if LC_COMP is equal to three, otherwise zero. In univariate analysis, we include all the three dummy variables in ICC regressions and suppress the constant term for direct comparison of the ICC in the three stages of corporate life cycle. In multiple regression, we omit the first dummy to serve as a reference category.

We control for five firm-specific risk-proxies in the ICC regression. Extant literature shows that firm size, systematic risk (measured by beta), book-to-market ratio, leverage, and idiosyncratic risk are proxies for different types of risk and have a role in explaining variations in equity-risk premium (see, Fama and French (1992); Gebhardt et al. (2001); Gode and Mohanram (2003) Larger firms are more diversified, have lower probability of bankruptcy (Berger \& Udell, 1998; Titman \& Wessels, 1988), and do not face severe problem of information asymmetry (Pettit \& Singer, 1985). Therefore, we expect a negative relationship between firm size and implied cost of equity. We measure firm size as the natural log of total assets. We control for a firm's exposure to market risk factor that is measured as the ratio of covariance of asset returns with the market returns to variance of the market returns (beta). On one hand, previous researches show lack of consensus on the relevance of beta in explaining observed returns; while on the other hand, ample evidence exists in support of beta in determining expected returns (Gode \& Mohanram, 2003; Botosan \& Plumlee, 2005; Harris \& Marston, 1992; Lintner, 1965; Sharpe, 1964). Growing firms have generally a higher ratio of intangible assets and face higher uncertainty regarding project success and failure. Thus, a positive relationship is expected between implied cost of equity and growth opportunities (Boone, Khurana, \& Raman, 2008; Gebhardt et al., 2001; Fama \& French, 1992). We measure growth opportunities as the ratio of bookto-market. Financial leverage increases the chances of financial distress and bankruptcy, and therefore, is expected to positively influence cost of equity (Chen, Jorgensen, \& Yoo, 
2004; Fama \& French, 1992; Hamada, 1972; Miller \& Friesen, 1984). We also included idiosyncratic risk as a control variable because Pakistan Stock Exchange is known to be a shallow market, where number of actively traded stocks remain in the range $40 \%$ to $50 \%$ of the total listed firms. One reason behind this might be the dominance of family ownership which results in limited number of free-float of shares. Therefore, it is expected that shareholders do not hold completely diversified portfolios and are exposed idiosyncratic risk of firms. Malkiel and Xu (2002); Chen et al. (2004) argue that there is a positive relationship between idiosyncratic risk and implied cost of equity. Idiosyncratic risk is calculated as the standard error of the CAPM regression.

\section{Results and Discussion}

This section presents and discusses descriptive statistics, correlation analysis, results of univariate analysis, and regression analysis ${ }^{18}$.

\section{Descriptive Statistics}

Table 2 presents descriptive statistics of the variables used in the study. The means of implied cost of equity calculated with MPEG model, Gordon growth model, and OJ model for the non-financial firms of Pakistan are 38.3\%, 36.7\%, 38.5\%, respectively. The mean values of all the three models are close enough, implying that ICC calculations are not influenced substantially by a choice of a specific model. Whereas mean ICC of the three models (Mean_ICC) is 39.6\% for the non-financial firms of Pakistan with a standard deviation of $22.6 \%$. Since there are missing ICC values, the Mean_ICC was calculated where at least two non-missing values of the three models were present. This approach helped in increasing observations available for regression analysis. One reason why the Mean_ICC is higher than the individual ICCs of the three models is the increase in number of observations, owing to the approach mentioned above for calculating the mean.

Implied cost of equity is higher in Pakistan when compared with other countries. For example, Hasan et al. (2015) report an implied cost of equity of $18.5 \%$ with a standard deviation of $13.3 \%$ using MPEG model for a sample of Australian non-financial firms. Whereas Botosan and Plumlee (2005), using Ohlson and Juettner-Nauroth (2005) model, report implied cost of equity of $20.1 \%$ for US firms. While this comparison shows that equity-risk premium is quite higher in Pakistan, it is also a fact that Pakistan has seen natural catastrophes, political turmoil (S. M. M. Shah \& Abdullah, 2015), economic difficulties, and deterioration in law and order situation over the last two decades. The KSE-100 index reflects these characteristics of Pakistani market over its life. The index has seen several episodes of booms and busts (Mallik \& Chowdhury, 2001). Further, many firms are owned by families (W. Ullah, Ali, \& Mehmood, 2017; S. Ullah \& Kamal, 2017) that engenders the problem of information asymmetry. Therefore, it is not surprising to see that shareholders demand such a higher premium on investments in Pakistan.

\footnotetext{
${ }^{18}$ All the tables were created using asdoc, a Stata program written by A. Shah (2018).
} 
Table 2

Descriptive Statistics

\begin{tabular}{lccccc}
\hline Variable & Obs. & Mean & Std. Dev. & Minimum & Maximum \\
\hline MPEG_ICC & 1515 & 0.383 & 0.233 & 0.001 & 0.999 \\
GORD_ICC & 2005 & 0.366 & 0.246 & 0.001 & 0.997 \\
OJ_ICC & 2004 & 0.385 & 0.245 & 0.001 & 0.997 \\
Mean_ICC & 2624 & 0.396 & 0.226 & 0.001 & 0.997 \\
BETA & 2564 & 0.457 & 0.656 & -4.598 & 4.605 \\
SE & 2372 & 0.045 & 0.043 & 0.0098 & 0.242 \\
SIZE & 6178 & 6.793 & 1.933 & -2.453 & 13.839 \\
LEVERAGE & 5580 & 0.558 & 0.216 & 0 & 0.995 \\
MB & 3846 & 2.092 & 53.109 & 0.0001 & 251.637 \\
\hline NOTE: MPEG_ICC, GORD_ICC, and OJ_ICC are the implied \\
cost of equity estimate of Easton (2004) model, Gordon and Gordon (1997), \\
and Ohlson and Juettner-Nauroth (2005) model, respectively. Mean_ICC is the \\
mean implied cost of equity of the three models. BETA is calculated by \\
regressing 60 months prior stock returns of a firm on the market returns, \\
SE is the standard error from the BETA regression as mentioned in the \\
preceding sentence.
\end{tabular}

\section{Correlation Analysis}

Table 3 reports the correlation coefficients between the variables used in the study. The composite life cycle proxy is negatively correlated with all the implied cost of equity models i.e. MPEG (-0.22), Gordon (-0.06), OJ (-0.127), and Mean_ICC (-0.168), showing that an inverse relationship exists between implied cost of equity and corporate life cycle stages in the non-financial sector of Pakistan. Almost all of the individual life cycle variables of Anthony and Ramesh (1992) are also negatively correlated with the ICC estimates of different models, except the sales growth (LC_SG) showing a positive correlation with MPEG (0.076), Gordon (0.0079) and Mean_ICC (0.0325). Moreover, in line with the expectations, Mean_ICC is negatively correlated with firm size and positively correlated with idiosyncratic risk (SE), leverage, and MB ratio. However, ICC is negatively correlated with systematic risk (beta), which is against the expectations.

\section{Univariate Analysis}

Table 4 reports the results of the regression analysis where dependent variables are implied cost of equity and independent variables are three dummy variables based on the composite corporate life cycle proxy (LC_COMP). All the three dummies are included in the regression test while suppressing the intercept term (i.e. using no base category for dummy variables). This technique is helpful in direct comparison of ICC in the three stages of firm life cycle. These tests do not include other control variables. The objective here is to test whether corporate life cycle proxies alone can explain the variation in implied cost of equity. In Table 4, column 2 through column 5 represent the coefficients of independent variables of corporate life cycle proxies where dependent variables are implied cost of equity calculated with MPEG model, Gordon model, OJ model, and Mean_ICC, respectively. Standard errors are given in parentheses beneath the coefficients of respective variables. Statistical significances at $1 \%, 5 \%$, and $10 \%$ are shown by $* * *, * *, *$, respectively. 


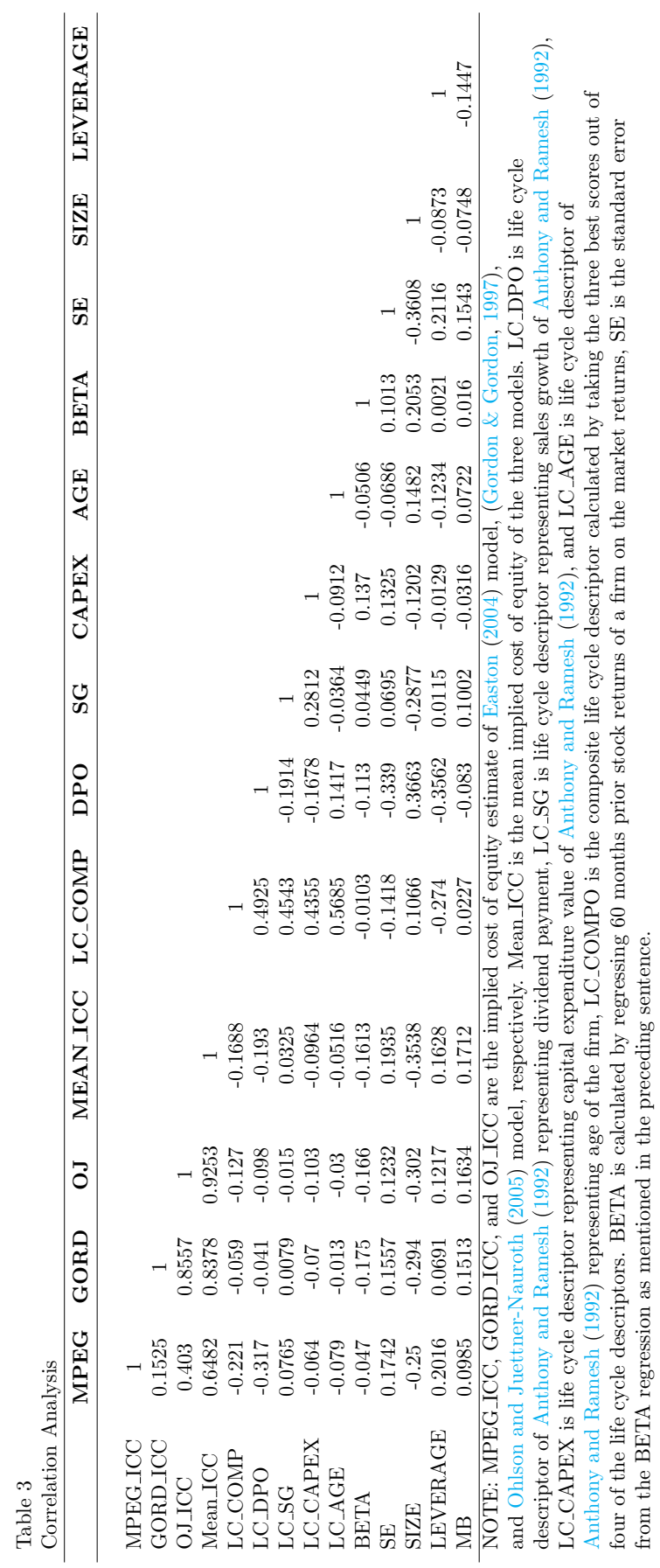


Table 4

Univariate Analysis of ICC and Corporate Life Cycle Stages

\begin{tabular}{lcccc}
\hline & $\mathbf{- 1}$ & $\mathbf{- 2}$ & $\mathbf{- 3}$ & $\mathbf{- 4}$ \\
VARIABLES & Mean_ICC & MPEG & GORD & OJ \\
\hline \multirow{2}{*}{ 1. LC_COMPO } & $0.437^{* * *}$ & $0.424^{* * *}$ & $0.388^{* * *}$ & $0.419^{* * *}$ \\
& -0.007 & -0.01 & -0.01 & -0.009 \\
2. LC_COMPO & $0.406^{* * *}$ & $0.391^{* * *}$ & $0.384^{* * *}$ & $0.385^{* * *}$ \\
& -0.007 & -0.01 & -0.009 & -0.009 \\
3. LC_COMPO & $0.333^{* * *}$ & $0.312^{* * *}$ & $0.315^{* * *}$ & $0.323^{* * *}$ \\
Observations & -0.008 & -0.011 & -0.01 & -0.01 \\
R-squared & 2,622 & 1,402 & 1,930 & 1,879 \\
\hline
\end{tabular}

NOTE: MPEG, GORD, and OJ are the implied cost of equity estimates of Easton (2004) model, Gordon and Gordon (1997), and Ohlson and Juettner-Nauroth (2005) model, respectively. Mean_ICC is the mean implied cost of equity of the three models. 1.LC_COMP is a dummy variable that takes the value of one if composite life cycle proxy is equal to one (growth stage), otherwise zero; 2.LC_COMP is a dummy variable that takes the value of one if composite life cycle proxy is equal to two (maturity stage), otherwise zero; and 3.LC_COMP takes the value of one if composite life cycle proxy is equal to three (stagnant stage), otherwise zero. The ${ }^{* * *}, * *$, and $*$ show statistical significance at $1 \%, 5 \%$, and $10 \%$ level, respectively. Standard errors are given in parentheses beneath the coefficients of respective variables.

Table 4 shows that the implied cost of equity is highest in growth stage, and then it gradually decrease in maturity stage and stagnant stages. This is the case in all four models of implied cost of equity. For example, in model (1) where the dependent variable is Mean_ICC, implied cost of equity is 0.437 in the growth stage, 0.406 in the maturity stage, and 0.333 in the stagnant stage. It is also important to note that the estimates of ICC in different models across the corporate life cycle stages are close enough. Therefore, the results show robustness to using alternative models of ICC. The univariate analysis clearly lends support to our primary and sub-hypotheses which state that implied cost of equity systematically decreases as a firm progresses through its life cycle stages.

Figure 1

Mean Implied Cost of Equity by Life Cycle Stages

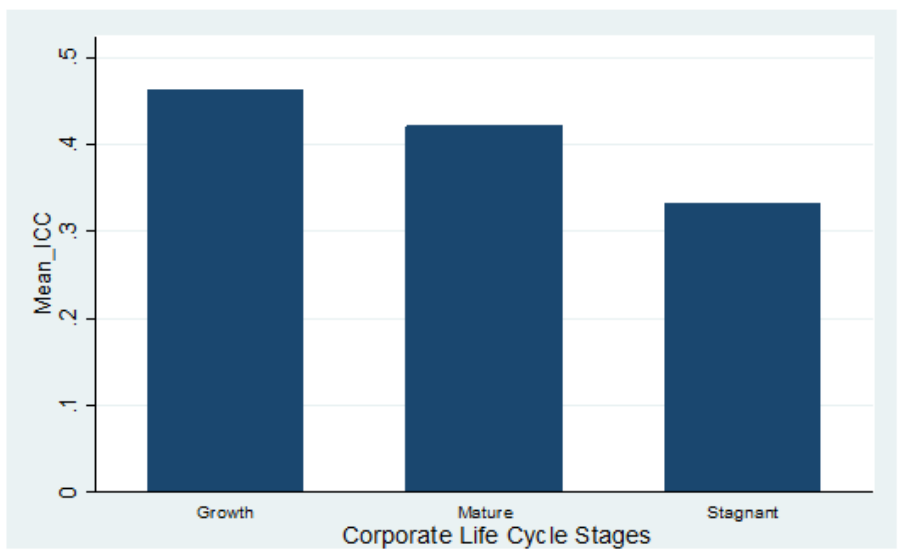


Graph 1 also depicts a similar trend in implied cost of equity when we plot the Mean_ICC against the three life cycle stages. The implied cost of equity gradually decreases as firm passes through growth, maturity and stagnant stages of its life cycle.

\section{Multiple Regression Analysis}

Before estimating the regression models, we ran regression diagnostic test to check for heteroscedasticity, multicollinearity, autocorrelation, outliers and influential observation. Results of these tests are not reported for the sake of parsimony. They can be provided upon request. Table 5 reports results of regressions where dependent variables are implied cost of equity estimates calculated through three different models and independent variables are composite corporate life cycle proxy and five control variables. The composite corporate life cycle proxy assumes values of 1, 2, and 3 for growth, maturity, and stagnant stages, respectively. These values are calculated each year for each firm as per the expectations for firm-specific descriptors of life cycle stages, shown in Table 1. First column of Table 5 shows names of the explanatory variables, whereas column 2 through column 5 report coefficients of these explanatory variables where dependent variables are ICC estimates calculated with MPEG, Gordon, OJ, and Mean_ICC models, respectively. Statistical significance is denoted by $* * *, * *$, and $*$, at $1 \%, 5 \%$, and $10 \%$ levels of significance, respectively.

In all the four models of ICC, results indicate that implied cost of equity is negatively associated with composite corporate life proxy (LC_COMP), though the coefficient of LC_COMP in the Gordon Model is not statistically significant. This implies that the cost of equity decreases systematically as a firm progresses through its life cycle stages even after controlling for other well-known determinants of cost of equity. This finding supports the results of the univariate analysis, discussed in the previous section. The negative sign of LC_COMP coefficient is in line with the primary hypothesis (H1) of this study. Economic significance can be demonstrated using the Mean_ICC under column heading (4). For instance, a one standard deviation increase in LC_COMP results in $5.35 \%$ reduction in implied cost of equity.

The results also imply that larger firms face lower cost of equity as indicated by the negative coefficient sign of the variable SIZE. The results are significant at $1 \%$ level in all models of ICC. The negative sign of SIZE is in line with the famous size premium hypothesis (Banz, 1981; Fama \& French, 1992, 1993) which states that smaller firms are considered to be more risky, in return shareholders demand higher equity premium on shares of these firms. Also, if firm size is taken as a proxy of information asymmetry as suggested by Pettit and Singer (1985), then the results support the notion that since small firms face higher information asymmetry problems, they face higher implied cost of equity. Furthermore, the coefficient of MB is positive in all models of ICC and is significant in MPEG and OJ models. A firm with higher market value of equity relative to book value of its equity is considered to be a growing firm. Thus, the results show partial support to the notion that growing firms face higher cost of equity. The results also indicate that firms with higher level of operational and financial risk are subjected to a higher cost of equity by shareholders. The coefficients of LEVERAGE (total debt/assets ratio) and SE (idiosyncratic risk) are positive and significant in all models of ICC, except the Gordon 
model where SE has negative coefficient which is statistically insignificant. And finally, proxy of systematic risk is unexpectedly negative but statistically insignificant in all models except in OJ model. It is not surprising to see insignificant negative coefficient of beta as a number of studies have documented a negative relation between beta and expected returns (Glosten et al., 1993; Lettau et al., 2007; Brandt \& Kang, 2004). While the literature provides mixed results regarding the relationship between beta and implied cot of equity capital, we tend to agree with Fama and French (1992) who concluded that when beta is included as explanatory variable in the presence of size, leverage, and market-to-book ratio, then the effects of beta are absorbed by the other variables.

Table 5

Multiple Regression Results

\begin{tabular}{|c|c|c|c|c|}
\hline & -1 & -2 & -3 & -4 \\
\hline VARIABLES & MPEG & GORDON & OJ & Mean_ICC \\
\hline \multirow{2}{*}{ LC_COMPO } & $-0.0301^{* * *}$ & -0.0165 & $-0.0200^{* *}$ & $-0.0264^{* * *}$ \\
\hline & -0.011 & -0.01 & -0.0101 & -0.00761 \\
\hline \multirow{2}{*}{ BETA } & -0.00275 & -0.0204 & $-0.0347^{* *}$ & -0.0148 \\
\hline & -0.0163 & -0.015 & -0.0144 & -0.0111 \\
\hline \multirow{2}{*}{ SE } & $1.426^{* * *}$ & -0.0491 & $1.660^{* * *}$ & $1.064^{* * *}$ \\
\hline & -0.399 & -0.402 & -0.335 & -0.245 \\
\hline \multirow{2}{*}{ SIZE } & $-0.0167^{* * *}$ & $-0.0300^{* * *}$ & $-0.0390 * * *$ & $-0.0269^{* * *}$ \\
\hline & -0.00633 & -0.00598 & -0.00625 & -0.00427 \\
\hline \multirow{2}{*}{ LEVERAGE } & $0.126^{* * *}$ & 0.0396 & $0.0750^{* *}$ & $0.0687^{* *}$ \\
\hline & -0.0395 & -0.0374 & -0.0373 & -0.0275 \\
\hline \multirow{2}{*}{ MB } & $0.00338^{* * *}$ & 0.00011 & $0.00286^{* * *}$ & 0.0001 \\
\hline & -0.00106 & -0.0002 & -0.0009 & -0.0001 \\
\hline \multirow{2}{*}{ Constant } & $0.488^{* * *}$ & $0.706^{* * *}$ & $0.667^{* * *}$ & $0.643^{* * * *}$ \\
\hline & -0.064 & -0.06 & -0.0605 & -0.0434 \\
\hline Observations & 786 & 1,140 & 1,026 & 1,522 \\
\hline R-squared & 0.201 & 0.186 & 0.246 & 0.228 \\
\hline Fixed effects & YES & YES & YES & YES \\
\hline
\end{tabular}

NOTE: Table 5 reports the regression results where dependent variable is implied cost of equity calculated through MPEG, Gordon, OJ, and Mean_ICC models and independent variables are composite corporate life cycle proxy of Anthony and Ramesh (1992) and control variables. The column titled MPEG, GORD, OJ, Mean_ICC report regression results where the dependent variables are the implied cost of equity estimates of Easton (2004) model, Gordon and Gordon (1997); Ohlson and Juettner-Nauroth (2005) and mean ICC of the other three models, respectively. LC_COMPO is the composite life cycle descriptor calculated by taking the three best scores out of four of the life cycle descriptors. BETA is calculated by regressing 60 months prior stock returns of a firm on the market returns, SE is the standard error from the BETA regression as mentioned in the preceding sentence. The ${ }^{* * *},{ }^{* *}$, and $*$ show statistical significance at $1 \%, 5 \%$, and $10 \%$ level, respectively. Standard errors are given in parentheses beneath the coefficients of respective variables. 
Table 6

Life Cycle Dummies in the ICC Regressions

\begin{tabular}{|c|c|c|c|c|}
\hline VARIABLES & $\begin{array}{c}-1 \\
\text { MPEG }\end{array}$ & $\begin{array}{c}-2 \\
\text { GORDON }\end{array}$ & $\begin{array}{l}-3 \\
\text { OJ }\end{array}$ & $\begin{array}{c}-4 \\
\text { Mean_ICC }\end{array}$ \\
\hline \multirow[t]{2}{*}{ 2.LC_COMPO } & -0.0164 & 0.0041 & -0.00921 & -0.021 \\
\hline & -0.0192 & -0.0178 & -0.0179 & -0.0133 \\
\hline \multirow[t]{2}{*}{ 3.LC_COMPO } & $-0.0611^{* * *}$ & $-0.0332^{*}$ & $-0.0404^{* *}$ & $-0.0532^{* * * *}$ \\
\hline & -0.0221 & -0.0201 & -0.0202 & -0.0152 \\
\hline \multirow[t]{2}{*}{ BETA } & -0.00191 & -0.0198 & $-0.0338^{* *}$ & -0.0146 \\
\hline & -0.0163 & -0.015 & -0.0144 & -0.0111 \\
\hline \multirow[t]{2}{*}{$\mathrm{SE}$} & $1.447^{* * *}$ & -0.045 & $1.666^{* * * *}$ & $1.068^{* * *}$ \\
\hline & -0.4 & -0.402 & -0.335 & -0.245 \\
\hline \multirow[t]{2}{*}{ SIZE } & $-0.0167^{* * *}$ & $-0.0299^{* * *}$ & $-0.0392 * * *$ & $-0.0269^{* * *}$ \\
\hline & -0.00633 & -0.00598 & -0.00626 & -0.00427 \\
\hline \multirow[t]{2}{*}{ LEVERAGE } & $0.125^{* * *}$ & 0.0382 & $0.0733^{* *}$ & $0.0682^{* *}$ \\
\hline & -0.0396 & -0.0374 & -0.0374 & -0.0276 \\
\hline \multirow{2}{*}{ MB } & $0.00332^{* * *}$ & 0.00012 & $0.00283^{* * *}$ & 0.000172 \\
\hline & & -0.000209 & -0.000918 & -0.000182 \\
\hline \multirow[t]{2}{*}{ Constant } & $0.454^{* * *}$ & $0.683^{* * *}$ & $0.646^{* * *}$ & $0.615^{* * *}$ \\
\hline & -0.062 & -0.0578 & -0.0587 & -0.0419 \\
\hline Observations & 786 & 1,140 & 1,026 & 1,522 \\
\hline R-squared & 0.202 & 0.188 & 0.246 & 0.228 \\
\hline Fixed Effects & Yes & Yes & Yes & Yes \\
\hline \multicolumn{5}{|c|}{$\begin{array}{l}\text { NOTE: Table } 6 \text { reports the regression results where dependent variable is } \\
\text { implied cost of equity calculated through MPEG, Gordon, OJ, and Mean_ICC } \\
\text { models and independent variables are composite corporate life cycle dummies } \\
\text { based on Anthony and Ramesh (1992) and other control variables. The column } \\
\text { titled MPEG, GORD, OJ, Mean_ICC report regression results where the } \\
\text { dependent variables are the implied cost of equity estimates of Easton (2004) } \\
\text { model, (Gordon \& Gordon, 1997; Ohlson \& Juettner-Nauroth, 2005), and mean } \\
\text { ICC of the other three models, respectively. 1.LC_COMP is a dummy variable } \\
\text { that takes the value of one if composite life cycle proxy is equal to one (growth stage) } \\
\text { otherwise zero; } 2 . L C \text { COMP is a dummy variable that takes the value of one if } \\
\text { composite life cycle proxy is equal to two (maturity stage), otherwise zero; and } \\
\text { 3.LC_COMP takes the value of one if composite life cycle proxy is equal to three } \\
\text { (stagnant stage), otherwise zero. } 1 . \text { LC_COMP is omitted from the regression to server } \\
\text { as a reference category. BETA is calculated by regressing } 60 \text { months prior stock } \\
\text { returns of a firm on the market returns, SE is the standard error from the BETA } \\
\text { regression as mentioned in the preceding sentence. The } * * *, * * \text {, and } * \text { show statistical } \\
\text { significance at } 1 \%, 5 \% \text {, and } 10 \% \text { level, respectively. Standard errors are given in } \\
\text { parentheses beneath the coefficients of respective variables. }\end{array}$} \\
\hline
\end{tabular}

\section{Life Cycle Dummies in the ICC Regressions}

To test sub-hypotheses $H_{1 a}$ and $H_{1 b}$, we define three dummy variables to represent life cycle stages. For example, for LC_COMP (which is a composite life cycle descriptor based on four firm-specific variables as per expectations given in Table 1), we define a dummy variable 1.LC_COMP that takes the value of one if LC_COMP is equal to one, otherwise zero; then we define 2.LC_COMP that takes the value of one if LC_COMP is equal to two, otherwise zero; and define 3.LC_COMP that takes the value of one if LC_COMP is equal to three, otherwise zero. We omit the first dummy to serve as a reference category. For testing sub-hypothesis, we expect the coefficients of 2.LC_COMP and 3. LC_COMP to be lower than the coefficient of reference group (i.e. 1. LC_COMP) and hence expect them to have negative coefficients in the regression results. In addition to these dummy variables, we follow the same approach as discussed in the previous section to include firm and year dummies and firm-specific control variables in the four ICC models. The results 
are reported in Table 6 .

The results reported in Table 6 show that implied cost of equity is the highest in the growth stage, while it gradually decreases in the maturity, followed by the stagnant stage. The coefficients of the two dummy variable 2. LC_COMP and 3. LC_COMP are negative in all models of the ICC, except the coefficient of 2. LC_COMP in Gordon model. In support of the two sub-hypotheses, the coefficients of the two dummy variables together show that cost of equity is higher in growth stage as compared to maturity stage, and is higher in maturity stage as compared to stagnant stage. For example, in the Mean_ICC model, the coefficient of 2. LC_COMP is -0.0210 and the coefficient of 3 . LC_COMP is -0.0532 , which indicates that cost of equity in the maturity stage is less than the growth stage (reference category) by 0.021 units, and cost of equity in the stagnant stage is less than the growth stage by 0.077 units. This is the case in all models of the ICC. Other control variables maintain their coefficient signs and statistical significances as reported and discussed in the previous section.

The overall insight that emerges from the analysis support our hypotheses that were derived from the asymmetric information view, risk-return trade-off framework, and the resource-based view while investigating the effect of life cycle stages on implied cost of equity. The results strongly support the notion that implied cost of equity declines as the firm moves from growth stage to maturity stage and from maturity to stagnant stage of its life cycle. According to information asymmetry view, firms face considerable amount of information asymmetry in the introduction stage. Since the costs of adverse selection are higher with equity, shareholders demand higher equity risk premium from young and growing firms. Information asymmetry decreases as the firm grows older, with commensurate decrease in the cost of equity. The risk-return trade-off predicts that growing and young firms face substantial uncertainty regarding success of the new projects, consequently shareholders demand higher equity premium while investing in these firms. Mature and old firms have relatively stable cash flows and diversified business lines which make them less risky. Consequently, shareholders demand lower equity premium on shares of such firms. And finally, the resource-based view predicts that young and growing firm usually do not possess unique set of valuable resources which can attract potential shareholder. Lower demand for shares of these firm results in higher cost of equity. Whereas mature firms carry a bundle of unique resources which they have accumulated over the course of their lives. These resources attract large number of shareholders toward these firms. Higher demand not only increases their share prices, but also increases liquidity of their shares. This in turn reduces the equity premium on their shares.

\section{Robustness Checks}

We find that the growth stage experiences the highest cost of equity, followed by maturity stage and then the stagnant stage. However, it is possible that at the point of "decline" in life cycle, one may observe the increase of ICC instead of decrease, relative to growth stage. Therefore, we include a squared term of the life cycle proxy (COMPO) in the regressions. Our results show that both the LC_COMPO and its squared term are not statistically significant in any regression. 


\section{Conclusion}

In this study, we sought to answer the question whether the stages of corporate life cycle can explain variations in firms' implied cost of equity. We established a theoretical link between these two variables using asymmetric information view, risk-return trade-off framework, and the resource-based view. We developed and tested the hypothesis that as a firm passes through its life cycle stages, i.e. from growth to maturity and from maturity to stagnant, the implied cost of equity systematically decreases. For testing the hypothesis, we used a sample of 365 non-financial firms listed at the Pakistan Stock Exchange from the year 1996 to 2012 . The results of the study strongly support our hypothesis that the implied cost of equity and corporate life cycle stages are negatively related. Results reveal that the growth stage experiences the highest cost of equity, followed by maturity stage, and then the stagnant stage. The results hold in both the univariate analysis and in multiple regression analysis where we control for several firm-specific determinants of implied cost of equity. Moreover, our results are robust to estimating implied cost of equity using three different models and using an average of three of models.

Our findings have important implications for shareholders and creditors. Both these groups of investors are affected by information asymmetry and riskiness of the firm. Our findings imply that firm's age can serve as a useful indicator of firm riskiness. As a firm passes through its life-cycle stages, the riskiness of the firm gradually decreases, and so does the rate of return required by investors.

There are several possibilities that researchers can work upon in the future. First, in a recent paper (Dickinson, 2011) showed that life cycle classification based on Anthony and Ramesh (1992) procedure leads to somewhat biased classification of the stage of firms in the life cycle. Since life cycle classification based on Anthony and Ramesh (1992) requires a five-year history of variables, this leads to removing true "growth stage" firms from the sample. As a robustness check, future researchers can use Dickinson (2011) model.

Second, there is a small literature saying that firm life cycle is endogenous. Researchers should examine whether results are sensitive to endogeneity issue as Hasan et al. (2015) did. Third, there is a possibility that firms are classified in several quantile groups on the basis of their life-cycle stages to make portfolios. Then, using an asset pricing framework, one can investigate whether the portfolio alphas systematically change when we move from a portfolio of growing firms to a portfolio of mature and stagnant firms. This will further lend support to the risk-firm life cycle relationship. 


\section{References}

Anthony, J. H., \& Ramesh, K. (1992). Association between accounting performance measures and stock prices: A test of the life cycle hypothesis. Journal of Accounting and Economics, 15(2-3), 203-227.

Banz, R. W. (1981). The relationship between return and market value of common stocks. Journal of Financial Economics, 9(1), 3-18.

Basu, S. (1983). The relationship between earnings' yield, market value and return for NYSE common stocks: Further evidence. Journal of Financial Economics, 12(1), $129-156$.

Berger, A. N., \& Udell, G. F. (1998). The economics of small business finance: The roles of private equity and debt markets in the financial growth cycle. Journal of Banking \& Finance, 22(6-8), 613-673.

Bhandari, L. C. (1988). Debt/equity ratio and expected common stock returns: Empirical evidence. The Journal of Finance, 43(2), 507-528.

Black, E. L. (1998). Life-cycle impacts on the incremental value-relevance of earnings and cash flow measures. Journal of Financial Statement Analysis, 4, 40-57.

Black, F. (1972). Capital market equilibrium with restricted borrowing. The Journal of Business, 45(3), 444-455.

Boone, J. P., Khurana, I. K., \& Raman, K. K. (2008). Audit firm tenure and the equity risk premium. Journal of Accounting, Auditing 8 Finance, 23(1), 115-140.

Botosan, C. A., \& Plumlee, M. A. (2005). Assessing alternative proxies for the expected risk premium. The Accounting Review, 80(1), 21-53.

Brandt, M. W., \& Kang, Q. (2004). On the relationship between the conditional mean and volatility of stock returns: A latent VAR approach. Journal of Financial Economics, 72(2), 217-257.

Brown, S. J., Goetzmann, W., Ibbotson, R. G., \& Ross, S. A. (1992). Survivorship bias in performance studies. The Review of Financial Studies, 5(4), 553-580.

Chen, F., Jorgensen, B. N., \& Yoo, Y. K. (2004). Implied cost of equity capital in earningsbased valuation: International evidence. Accounting and Business Research, $34(4)$, 323-344.

Claus, J., \& Thomas, J. (2001). Equity premia as low as three percent? Evidence from analysts' earnings forecasts for domestic and international stock markets. The Journal of Finance, 56(5), 1629-1666.

Cooray, A., Paradiso, A., \& Truglia, F. G. (2013). Do countries belonging to the same region suggest the same growth enhancing variables? Evidence from selected South Asian countries. Economic Modelling, 33, 772-779.

Daske, H., Gebhardt, G., \& Klein, S. (2006). Estimating the expected cost of equity capital using analysts' consensus forecasts. Schmalenbach Business Review, 58(1), 2-36.

Diamond, D. W. (1989). Reputation acquisition in debt markets. Journal of Political Economy, 97(4), 828-862.

Dickinson, V. (2011). Cash flow patterns as a proxy for firm life cycle. The Accounting Review, 86(6), 1969-1994. 
Easton, P. D. (2004). PE ratios, PEG ratios, and estimating the implied expected rate of return on equity capital. The Accounting Review, 79(1), 73-95.

Estrada, J. (2001). The cost of equity in emerging markets: A downside risk approach. Emerging Markets Quarterly, 5(1), 63-72.

Fama, E. F., \& French, K. R. (1992). The cross-section of expected stock returns. The Journal of Finance, $47(2), 427-465$.

Fama, E. F., \& French, K. R. (1993). Common risk factors in the returns on stocks and bonds. Journal of Financial Economics, 33(1), 3-56.

Fan, J. P., \& Wong, T. J. (2002). Corporate ownership structure and the informativeness of accounting earnings in East Asia. Journal of Accounting and Economics, 33(3), $401-425$.

Fluck, Z. (2000). Capital structure decisions in small and large firms: A life-cycle theory of financing (Unpublished doctoral dissertation). Arizona, Duke: Stern School of Business, New York University.

Gebhardt, W. R., Lee, C. M., \& Swaminathan, B. (2001). Toward an implied cost of capital. Journal of Accounting Research, 39(1), 135-176.

Glosten, L. R., Jagannathan, R., \& Runkle, D. E. (1993). On the relation between the expected value and the volatility of the nominal excess return on stocks. The Journal of Finance, 48(5), 1779-1801.

Gode, D., \& Mohanram, P. (2003). Inferring the cost of capital using the Ohlson-Juettner model. Review of Accounting Studies, 8(4), 399-431.

Gordon, J. R., \& Gordon, M. J. (1997). The finite horizon expected return model. Financial Analysts Journal, 53(3), 52-61.

Greiner, L. (1998). Evolution and revolution as organizations grow-Larry E. Greiner responds. Harvard Business Review, 50, 37-46.

Hamada, R. S. (1972). The effect of the firm's capital structure on the systematic risk of common stocks. The Journal of Finance, 27(2), 435-452.

Harris, R. S., \& Marston, F. C. (1992). Estimating shareholder risk premia using analysts' growth forecasts. Financial Management, 21(2), 63-70.

Hasan, M. M., Hossain, M., Habib, A., et al. (2015). Corporate life cycle and cost of equity capital. Journal of Contemporary Accounting \& Economics, 11 (1), 46-60.

Hausman, J. A. (1978). Specification tests in econometrics. Econometrica: Journal of the Econometric Society, 1251-1271.

Hou, K., Van Dijk, M. A., \& Zhang, Y. (2012). The implied cost of capital: A new approach. Journal of Accounting and Economics, 53(3), 504-526.

Konečnỳ, Z. (2013). Structure of cost of equity as the dependence on the corporate-and market life cycle. Trends Economics and Management, 6(10), 54-67.

La Rocca, M., La Rocca, T., \& Cariola, A. (2011). Capital structure decisions during a firm's life cycle. Small Business Economics, 37(1), 107-130.

Lee, C., So, E., \& Wang, C. (2010). Evaluating implied cost of capital estimates. SSRN eLibrary, 6, 1-38.

Lester, D. L., Parnell, J. A., \& Carraher, S. (2003). Organizational life cycle: A fivestage empirical scale. The International Journal of Organizational Analysis, 11(4), 339-354. 
Lettau, M., Ludvigson, S. C., \& Wachter, J. A. (2007). The declining equity premium: What role does macroeconomic risk play? The Review of Financial Studies, 21(4), $1653-1687$.

Lintner, J. (1965). The valuation of risk assets and the selection of risky investments in stock portfolios and capital budgets. Review of Economics and Statistics, $47(1)$, 13-37.

Lippitt, G. L., \& Schmidt, W. H. (1967). Crises in a developing organization. Harvard Business Review, 45(6), 102-112.

Malkiel, B. G., \& Xu, Y. (2002). Idiosyncratic risk and security returns. University of Texas at Dallas.

Mallik, G., \& Chowdhury, A. (2001). Inflation and economic growth: Evidence from four South Asian countries. Asia-Pacific Development Journal, 8(1), 123-135.

McNulty, J. J., Yeh, T. D., Schulze, W. S., \& Lubatkin, M. H. (2002). What's your real cost of capital? Harvard Business Review, 80(10), 114-121.

Miller, D., \& Friesen, P. H. (1984). A longitudinal study of the corporate life cycle. Management Science, 30(10), 1161-1183.

Myers, S. C. (1984). The capital structure puzzle. The Journal of Finance, 39(3), 574-592.

Myers, S. C., \& Majluf, N. S. (1984). Corporate financing and investment decisions when firms have information that investors do not have. Journal of Financial Economics, 13(2), 187-221.

Ohlson, J. A., \& Juettner-Nauroth, B. E. (2005). Expected EPS and EPS growth as determinants of value. Review of Accounting Studies, 10(2-3), 349-365.

Pástor, L., Sinha, M., \& Swaminathan, B. (2008). Estimating the intertemporal riskreturn tradeoff using the implied cost of capital. The Journal of Finance, 63(6), 2859-2897.

Penrose, E. (1959). The theory of the growth of the firm. New York: John Wiley.

Pettit, R. R., \& Singer, R. F. (1985). Small business finance: A research agenda. Financial Management, $14(3), 47-60$.

Phelps, R., Adams, R., \& Bessant, J. (2007). Life cycles of growing organizations: A review with implications for knowledge and learning. International Journal of Management Reviews, 9(1), 1-30.

Ross, S. A. (1977). The determination of financial structure: The incentive-signalling approach. The Bell Journal of Economics, 8(1), 23-40.

Rumelt, R. P. (1984). Towards a strategic theory of the firm. Englewood Cliffs, New Jersy: Prentice-Hall.

Seifert, B., \& Gonenc, H. (2012). Issuing and repurchasing: The influence of mispricing, corporate life cycle and financing waves. Journal of Multinational Financial Management, 22(3), 66-81.

Shah, A. (2018). ASDOC: Stata module to create high-quality tables in MS Word from Stata output.

Shah, S. M. M., \& Abdullah, F. (2015). A study of day of the week effect in Karachi stock exchange during different political regimes in Pakistan. Business E Economic Review, 7(1), 41-66. 
Sharpe, W. F. (1964). Capital asset prices: A theory of market equilibrium under conditions of risk. The Journal of Finance, 19(3), 425-442.

Shirokova, G. (2009). Organisational life-cycle: The characteristics of developmental stages in Russian companies created from scratch. Journal for East European Management Studies, 14(1), 65-85.

Stattman, D. (1980). Book values and stock returns. The Chicago MBA: A Journal of Selected Papers, 4(1), 25-45.

Thompson, H. E., \& Wong, W.-K. (1996). Revisiting "dividend yield plus growth" and its application. The Engineering Economist, 41(2), 123-147.

Titman, S., \& Wessels, R. (1988). The determinants of capital structure choice. The Journal of Finance, 43(1), 1-19.

Ullah, S., \& Kamal, Y. (2017). Board characteristics, political connections, and corporate cash holdings: The role of firm size and political regime. Business 8 Economic Review, 9(1), 157-179.

Ullah, W., Ali, S., \& Mehmood, S. (2017). Impact of excess control, ownership structure and corporate governance on firm performance of diversified group firms in Pakistan. Business \& Economic Review, 9(2), 49-72.

Wernerfelt, B. (1984). A resource-based view of the firm. Strategic Management Journal, $5(2), 171-180$.

Wong, W.-K., \& Chan, R. H. (2004). On the estimation of cost of capital and its reliability. Quantitative Finance, 4(3), 365-372. 